\title{
Methodological basis of forming organizational competence of future specialists in service industry
}

\author{
Ohui S.* \\ Poltava V.G. Korolenko National Pedagogical University, Poltava, Ukraine
}

Received: 12.03 .2019

Accepted: 15.04 .2019

\begin{abstract}
The purpose of this research is to characterize the methodological approaches in the system of forming organizational and methodological competence of future specialists in service industry as one of the most important personal qualities in professional activity. The research determines the main methodological approaches to forming organizational and methodological competence of future specialists in service industry and establishes the topicality of competence-based, personality-oriented, activity, and praxeological approaches for solving the issue of forming organizational and methodological competence of future specialists in restaurant service. The relevance of organizational and methodological competence for the employee's professional development and competitive value in the present-day labour market is emphasized. Consecutive stages of pedagogical projection of professional competences as outcomes of educational process are distinguished, including organizational and methodological competence of future specialists in restaurant service. The necessity of implementing personality-oriented educational environment in a harmonious combination with group and collective forms of learning is validated. The priority of the activity component in the structure of professional competences is proven, as it facilitates the application of profound theoretical knowledge for the solution of work problems and in non-standart, constantly changing life situations. The results of this research are of use for the development of competence-based pedagogical technologies. The research proves the importance of organizational and methodological competence for the swift adaptation of new specialists in restaurant service to highly changeable work conditions and for the ensuring effective professional interaction between all parties involved in service industry.

Key words: organizational and methodological competence, specialist in service industry, specialist in restaurant service, methodological approaches: competence-based, personality-oriented, activity, and competence-based.
\end{abstract}

\section{Методологічні основи формування організаційно-методичної компетентності майбутніх фахівців сфрери обслуговування}

\section{Огуй С. B.}

\author{
Полтавський національний педагогічний університет імені В. Г. Короленка, Полтава, Україна
}

\begin{abstract}
Анотація. В нашому дослідженні виділено основні методологічні підходи до формування організаційнометодичної компетентності майбутніх фахівців сфери обслуговування, здійснено обґрунтування компетентністного, діяльністного, особистісно-орієнтованого та праксеологічного підходів при вирішенні проблеми формування організаційно-методичної компетентності майбутніх фахівців ресторанного обслуговування. Акцентовано увагу на значенні організаційної компетентності у професійному становленні й конкурентоспроможності працівника на сучасному ринку праці. Визначено послідовні етапи технології педагогічного проектування професійних компетентностей як освітніх результатів навчання, до складу яких ми відносимо й організаційно-методичну компетентність майбутніх фрахівців ресторанного обслуговування.

Ключові слова: організаційно-методична компетентність, фрахівець сфери обслуговування, фрахівець ресторанного обслуговування, методологічні підходи: компетентністний, діяльністний, особистісноорієнтований та праксеологічний.
\end{abstract}

\footnotetext{
Corresponding Author: Ohui Svitlana Volodymyrivna. E-mail: svetlana.oguj@gmail.com Poltava V.G. Korolenko National Pedagogical University, vul. Ostrohradskoho, 2, Poltava, Ukraine, 36000.

Відповідальний автор: Огуй Світлана Володимирівна. E-mail: svetlana.oguj@gmail.com Полтавський національний педагогічний університет імені В. Г. Короленка, вул. Остроградського, 2, м. Полтава, Україна, 36000.
} 


\title{
Методологические основы формирования организационной компетенции будущих специалистов сферы обслуживания
}

\author{
Огуй С. B.
}

Полтавский национальный педагогический университет имени В. Г. Короленка, Полтава, Украина

\begin{abstract}
Аннотация. В нашем исследовании выделены основные методологические подходы к формированию организационно-методической компетентности будущих специалистов сферы обслуживания, осуществлено обоснование компетентностного, деятельностного личностно-ориентированного и праксеологического подходов при решении проблемы, связанной с формированием организационно-методической компетентности будущих специалистов ресторанного обслуживания. Акцентировано внимание на значении организационно-методической компетентности в профессиональном становлении и конкурентоспособности работника на современном рынке труда. Определены последовательные этапы технологии педагогического проектирования профессиональных компетенций как образовательных результатов обучения, в состав которых мы относим и организационно-методическую компетентность будущих специалистов ресторанного обслуживания.

Ключевые слова: организационно-методическая компетентность, специалист сферы обслуживания, специалист ресторанного обслуживания, методологические подходы: компетеностный, деятельностный, личностно-ориентированный и праксеологический.
\end{abstract}

\section{Bemyn}

Сучасний ринок праці, з його високою інноваційною динамікою, висуває нові вимоги до випускників навчальних закладів, в тому числі коледжів та технікумів. Серед основних вимог до випускників закладів вищої освіти, що готують фахівців сфери обслуговування виділяємо готовність до безперервної самоосвіти й підвищення професійної кваліфрікації; наявність ділової комунікативності; уміння роботи в команді; активна діяльність у нестандартних і невизначених ситуаціях; здатність приймати відповідальні рішення; критичне мислення; самоменеджмент; володіння навичками роботи 3 різними джерелами інформації тощо. При цьому треба врахувати, що вимоги роботодавців $є$ не стільки щодо «знань», скільки щодо способів діяльності - «уміння», «здатність», «готовність». Отже, йдеться про особливі результати навчання, де знання виступають необхідними, однак недостатніми умовами для досягнення високої якості освіти.

Невідкладність процесу реформування системи вищої освіти зумовлені різними чинниками.

По-перше, керівники підприємств дедалі частіше піднімають питання про якість освітньої підготовки. Здебільшого випускники володіють на належному рівні репродуктивними знаннями й уміннями, але якісне виконання професійних обов'язків потребує донавчання випускника безпосередньо на виробництві з витратами часу та коштів. Це зумовлено відсутністю конструктивної взаємодії між підприємствами та закладами вищої освіти. Вирішення даного питання можливе за умов об'єднання зусиль роботодавців, освітян і науковців задля перегляду змісту освітньо-професійних програм, розроблення базових та професійних компетентностей для окремої з врахуванням сучасних тенденцій розвитку виробничих технологій та оновлення змісту діючих державних стандартів.

По-друге, зовнішні та внутрішні економічні перетворення у сфері послуг посилили значення результативної діяльності суб'єктів освіти, що дає підстави визначати пріоритетним показником професіоналізму фахівця якість його роботи, готовність та здатність до виконання професійних функцій на робочому місці в реальних умовах. Відповідно до Національної доктрини розвитку освіти у XXI столітті забезпечення якості стає ключовою ідеєю, новою філософрією освіти, потенціалом навчальних закладів у розкритті можливостей у сфері освітньої діяльності [1, с. 17].

По-третє, якість профресійної підготовки фахівця не стільки залежить від успішного відтворення ним теоретичних знань (знаннєвої складової професійної компетентності), скільки від виконання ним трудових функцій (діяльнісного компоненту), що визначають результати навчання, а також компетентності, які набуває випускник закладу вищої освіти та здатен продемонструвати після завершення навчання. 
Аналіз типових навчальних планів та програм спонукає до перегляду обсягів теоретичних знань і практичної підготовки майбутніх фахівців сфери обслуговування, оновлення навчальних програм 3 теоретичних предметів із включенням інноваційних методів навчання, ситуаційних завдань професійного спрямування тощо.

По-четверте, сучасний ринок праці вимагає від випускника не лише глибоких теоретичних знань, а й здатності самостійно застосовувати їх у нестандартних, постійно змінюваних життєвих ситуаціях, переходу від суспільства знань до суспільства життєво-компетентних громадян [2, с. 112]. Реалізація означених вище чинників передбачає формування організаційно-методичної компетентності майбутніх фахівців сфери обслуговування, як значимої та професійно-важливої особистісної якості на усіх ланках освітньої системи. Теоретико-методологічним підґрунтям процесу формування організаційнометодичної компетенції майбутніх фахівців виступає сукупність методологічних підходів, завдяки яким досліджуване педагогічне явище, внаслідок своєї складності й багатоаспектності, розглядається з різних позицій.

Метою нашого дослідження є характеристика методологічних підходів у системі формування організаційно-методичної компетентності майбутніх фрахівців сфери обслуговування як однієї 3 важливих особистісних якостей у професійній діяльності. Для реалізації поставленої мети ми проаналізували праці відомих науковців та дослідили процес формування організаційної й методичної компетентностей, а також працездатності майбутнього фахівця індустрії обслуговування в закладах вищої освіти.

\section{II Матеріал і методи дослідження}

Вітчизняні та зарубіжні науковці визначають безліч підходів у системі формування професійної готовності майбутніх фахівців. У дослідженнях українських вчених (Л.Долинська, Л. Карамушка, М. Корольчук, О. Креденцер, С. Максименко, С. Миронець) висвітлено і практичні, і теоретичні питання - методологічні підходи, визначення понять, шляхи формування професійних якостей тощо. Зарубіжні науковці (В. Бодров, Л. Виготський, Д. Ельконіна, Р. Мартенес, Л. Меркур'єва, А. Леонтьева, $€$ П. Павлютенков, С. Рубінштейн, М. Савіна, А. Сазонова, В. Симоненко, О. Філь, С. Чистякова) на перший план висувають діяльністний підхід.

Аналізуючи праці вітчизняних та закордонних науковців ми концентрували наше дослідження на обгрунтуванні компетентністного, діяльністного, особистісно-орієнтованого та праксеологічного підходів при вирішенні проблеми формування організаційно-методичної компетентності майбутніх фрахівців сфрери обслуговування.

Компетентністний підхід до оновлення освіти в Україні започаткований у 2013 році, орієнтований на загальноєвропейські процеси ресрормування та розвитку освіти та державно прийнятий і схвалений рядом нормативних документів, зокрема Національною стратегією розвитку освіти в Україні на період до 2021 рік [3].

Компетентність виникла з потреби в адаптації людини до занадто мінливих умов існування, зазначає О. Пометун [4]. На думку В. Радкевич, ключові компетентності - це загальні здібності й уміння, що дають змогу особі розуміти ситуацію, досягати успіху в особистісному й професійному житті набувати соціальної самостійності та забезпечувати ефективну професійну взаємодію. Ключові компетентності ґрунтуються на головних цілях загальної і професійної освіти тих, хто навчається, їхньому соціальному й особистісному досвіді, а також на основних видах діяльності [2, с. 115]. Серед ключових компетентностей науковці виділяють:

1) навчальну, що передбачає дві центральні ідеї: інтелектуальний розвиток особистості та її здатність учитися впродовж життя;

2) підприємницьку, що передбачає володіння засобами, що майбутньому фахівцеві надають можливість ефрективно організувати особисту та колективну трудову й підприємницьку діяльність;

3) соціальну, яка передбачає володіння сукупністю засобів, що забезпечують можливість особистості взаємодіяти з різними соціальними групами та соціальними інститутами суспільства;

4) громадянську, що передбачає формування здатності захищати та піклуватись про відповідальність, права, інтереси та потреби людини і громадянина, держави і суспільства; 
5) здоров'язбережувальну, що передбачає набуття студентами характеристик і властивостей, спрямованих на збереження фізичного, соціального, психічного і духовного здоров'я, свого та оточення;

6) компетентності 3 інформаційних та комунікаційних технологій передбачають здатність студента орієнтуватися в інформаційному просторі, володіти й оперувати інформацією відповідно до потреб ринку праці;

7) культурну, що передбачає здатність жити та взаємодіяти з іншими в умовах полікультурного суспільства, керуючись національними та загальнолюдськими цінностями;

8) професійну, яка спрямована на засвоєння та оволодіння професійно значущих знань, умінь та навичок, розвиток професійної самосвідомості.

Кожна з ключових компетентностей передбачає засвоєння особистістю не окремих непов'язаних один з одним елементів знань і умінь, а оволодіння комплексною процедурою, в якій кожному виділеному напряму її набуття відповідає сукупність освітніх компонентів, що мають особистіснодіяльнісний характер [5].

Технологія педагогічного проектування ключових компетентностей як освітніх результатів навчання включає такі послідовні етапи:

1) визначення переліку ключових компетентностей для фахівців ресторанного обслуговування;

2) перелік компетенцій для даних фрахівців;

3) розроблення навчально-методичного забезпечення для формування ключових компетентностей;

4) відбір педагогічних технологій;

5) визначення методів і критеріїв оцінювання рівня сфрормованості ключових компетентностей.

Більшість публікацій, які висвітлюють проблему компетентнісного підходу, присвячено розгляду ключових компетентностей, а професійним та предметним компетентностям ученими приділено недостатньої уваги, ці проблеми знаходяться в стані розробки.

Виділяючи діяльністний підхід у формуванні компетентностей майбутніх фрахівців сфери обслуговування ми спробували визначити складові професійної компетентності як важливого особистісного утворення, важливого та необхідного для успішного здійснення професійної діяльності.

Професійні або фахові компетентності відображають специфіку професійної діяльності у певній галузі чи сфері. Професійна компетентність - головний критерій, за яким оцінюється персонал будь-якої організації чи компанії. Це здатність фахівця вирішувати певний клас профресійних завдань у комплексному їх представленні. У фрормальному розумінні під компетентністю можна розуміти опис вимог до особистісних, професійних, когнітивних якостей, яким повинен відповідати фахівець певної сфрери діяльності [6].

До професійних компетентностей майбутніх фахівців сфери обслуговування відносимо такі:

- теоретико-технологічна - наявність системи професійних знань, спроможність інтеграції знань у нових ситуаціях, здатність до ефективних розв'язань традиційних та нетрадиційних завдань,самостійно одержувати інформацію, постійно підвищувати освітній рівень;

- виробничо-технологічна - здатність планувати технологічні процеси, використовувати досвід інших, володіння інформаційними технологіями;

- соціально-комунікативна - готовність до взаєморозуміння та взаємодії у комунікації та стосунках, здатність до обговорення та прийняття спільних рішень, здатність брати відповідальність за їх реалізацію на себе, здатність уникати конфліктів, толерантно розв'язувати їх між іншими учасниками виробничого колективу;

- організаційно-методична - професійна мобільність, здатність проектувати власну діяльність та діяльність співробітників, враховуючи потреби клієнтів, творчий підхід до роботи з колективом, здатність суміщення власних інтересів та потреб підприємства і суспільства, здатність до постійного підвищення освітнього рівня, потреба в актуалізації й реалізації власного потенціалу, здатність точно і коректно передавати знання, формулювати вимоги, завдання підлеглим тощо. 


\section{III Результати}

Аналіз наукових праць свідчить, що процес фрормування організаційно-методичної компетентності майбутніх фахівців сфрери обслуговування досліджено недостатньо. Зокрема, потребують обгрунтування методологічні підходи до системи формування організаційно-методичної компетентності майбутніх фрахівців готельно-ресторанного бізнесу. Однією із проблем $є$ те, що закладам готельноресторанного бізнесу не вистачає добре підготовлених фахівців, які б уміли застосовувати отримані теоретичні знання на практиці. Очевидним $€$ те, що лише фахівець з високим рівнем професіоналізму зможе бути конкурентоспроможним в сфері готельно-ресторанного бізнесу, здатним до активної роботи, глибокого аналізу ринкової ситуації, постійного самовдосконалення. Як джерело професійної підготовки, оновлення знань і перепідготовки кадрів важливо систематично враховувати тенденції, які виникають на ринку праці, а також у сферах економіки, права, готельного-ресторанного господарства, менеджменту тощо.

Серед першочергових завдань, що висуваються до освітніх закладів, $є$ забезпечення професійної підготовки фахівців нового типу, як повинні бути розумними, вправними та здатними у разі необхідності швидко перекваліфікуватися чи змінити професію, володіти професійною гнучкістю та мобільністю. Серед інших обов'язкових елементів кваліфікації сучасного працівника Г. Щокін виділяє належний рівень загальної освіти, широку професійну підготовку і високий культурно-технічний рівень, уміння швидко поновлювати та поповнювати знання.

Сучасний фахівець практично у будь-якій сфрері діяльності повинен володіти здатністю до абстрактного мислення, до роботи в творчих колективах, мати підготовку у сфері маркетингу, а також чітко уявляти собі господарські, організаційні, соціальні та культурні аспекти застосування нових технологій $[7$, с. 88].

У професійній педагогіці під поняттям «формування» розуміють процес становлення людини як соціальної істоти під впливом усіх фракторів: природних, економічних, соціальних, культурних, екологічних, політичних, ідеологічних, психологічних тощо. Людина, яка вирішила працювати у сфері обслуговування, стати фахівцем і присвятити себе розвитку цієї галузі, проходить низку етапів професійного становлення. Кожен із цих етапів - це певний ступінь підготовки, що вимагає володіння необхідним обсягом знань, умінь, навичок, особистісних професійних якостей. Для реалізації змісту зазначених етапів виникає потреба розробити навчально-методичний комплекс формування й розвитку професійних компетентностей фахівців ресторанного сервісу як складову професійної кваліфікації майбутнього робітника на основі сучасних педагогічних технологій. Основними завданнями такого навчального забезпечення є: 1) розвиток комунікативної, психологічної та організаційно-методичної компетентностей фрахівців ресторанного сервісу; 2) підвищення мотивації студентів технікумів і коледжів до здобуття обраної професії; 3) розвиток позитивного ставлення фахівця до самого себе й обраної ним професії; 4) розвиток умінь і навичок планування власного майбутнього професійного життя [8].

Важливою педагогічною умовою формування професійних компетентностей фахівців сфери обслуговування $€$ поетапність їх фрормування через систему знань, умінь і навичок. Перший етап ціннісно-змістовий, на я кому відбувається формування і усвідомлення мотивів і цінностей майбутньої професійної діяльності, співпадає з вивченням теоретичних дисциплін. Другий етап - інформаційнокогнітивний, де пріоритетом $€$ формування когнітивного компонента професійних компетентностей та інноваційними засобами виступають вивчення спеціальних дисциплін і проходження виробничих практик. Третій етап практично-технологічний, передбачає вивчення спецкурсів, які безпосередньо пов'язані з практичним освоєнням теоретичних знань, відбувається формування поведінкового та емоційно-вольового компонента професійних компетентностей.

Найважливішою рисою фахівця нової формації $€$ становлення організаційно-методичної компетентності. В її основу покладений зміст практичної підготовки майбутнього фахівця ресторанної справи, організація процесу практичної підготовки майбутнього фахівця; обірунтовано організаційно-педагогічні умови ефективного формування професійних умінь та методика фрормування професійних умінь майбутнього фахівця ресторанної справи. Вивчення особливостей професійної діяльності в закладах ресторанного господарства, динамічність та стрімкі зміни організаційних засад технічних та технологічних процесів виробництва продукції є складовими у визначенні основних підходів щодо вибору форм і методів 
професійно-практичної підготовки майбутніх фрахівців ресторанної справи [9]. Важливе значення у формуванні відповідних професійних умінь майбутнього фахівця ресторанної справи має його самостійна діяльність, спрямована на відпрацювання найважливіших складових майбутньої професії.

Організація навчально-виховного і навчально-виробничого процесу має здійснюватися за допомогою відповідних форм навчально-пізнавальної діяльності, що найбільшою мірою відтворюють реальні умови праці. На цій основі реалізується професійно-практична діяльність студентів.

Реалізація принципу міждисциплінарних зв'язків зумовлює певні вимоги до процесу організації професійного навчання з урахуванням взаємозв'язку теоретичної і навчально-виробничої підготовки. Практична підготовка майбутнього фахівця ресторанної справи має передбачати застосування фрорм навчально-пізнавальної діяльності, які забезпечують творчий, пошуковий характер професійних дій.

Формування комунікативних умінь професійного спілкування, моделювання у процесі підготовки реальних проблем та ситуацій дасть змогу розширити простір його професійної та соціальної взаємодії 3 галузевим середовищем. До речі, на практичні заняття й самостійну роботу доцільно відвести більшу частину навчального часу, оскільки ключові компетентності випускника проявляються не в репродуктивній, а у професійній діяльності і позначаються такими категоріями: вивчати, шукати, думати, співпрацювати, братись за справу, адаптовуватися тощо. Закріплення набутих компетенцій варто проводити за допомогою бесіди, діалогу, тестування, ситуативних вправ, ділових ігор, творчих проектів тощо.

\section{IV Обговорення}

Головною відмітною рисою компетентнісної освіти є підсилення суб'єктності (індивідуальності) здобувачів вищої освіти, надання навчанню особистісної значущості. Науковці підкреслюють при цьому важливість опори на ціннісні орієнтації студентів.

Особисто-орієнтований підхід до фрормування організаційно-методичної компетентності сприяє розв'язанню проблеми розвитку індивідуальності кожного студента. Для вирішення такої проблеми необхідне створення такого професійно орієнтованого навчального середовища, яке б забезпечувало свободу вибору індивідуальної освітньої траєкторії та відкривало можливості для самостійної роботи студентів, їх самовизначення та самореалізації. При цьому необхідна побудова професійного навчання у вигляді розв'язання ланцюга професійно орієнтованих задач-ситуацій. На думку І. Зимньої, психологопедагогічні проблеми розвитку сучасної освіти необхідно розглядати на основі особистісно діяльнісного підходу, згідно якого у центрі освітнього процесу знаходиться студент. Формування його особистості відбувається засобами кожного конкретного навчального предмета. Навчальний процес передбачає організацію і управління навчальною діяльністю студентів, спрямованою на їх усебічний розвиток i освоєння ними предметних знань [10].

Особистісно-орієнтована технологія навчання переводить на активну позицію всіх учасників навчального процесу. I викладач, і студент виступають суб'єктами навчання, мають право обирати траєкторію навчання, враховуючи можливості та бажання студента. Таким чином навчання переходить в площину самоосвіти, де викладач виконує роль консультанта (тьютора), який координує та спрямовує навчальну діяльність студентів, у формі діалогового спілкування.

Зміст навчання виступає засобом розвитку особистості студента та узгоджується з процесом його засвоєння, визначає механізми самоорганізації та освіти, розкриває кінцевого результат освітнього процесу. Реалізація особистісно-орієнтованого навчання передбачає поєднання традиційних методів 3 інноваційними (проблемне та перевернуте навчання, евристична бесіда, інтерактивні методи) з опорою на суб'єктивний досвід студентів.

Для реалізації процесу формування організаційно-методичної компетентності особистісноорієнтоване навчання дає ряд переваг: по-перше, потреба у засвоєнні знань дозволяє реалізувати у майбутньому професійну мобільність; по-друге, відбувається повне засвоєння соціального досвіду та набуття особистісного досвіду, що формує здатність проектувати власну діяльність та діяльність співробітників, здатність суміщення власних інтересів та потреб підприємства і суспільства; по-третє, набуття навичок творчої діяльності та ціннісних відносин впливають на формування здатності до постійного підвищення освітнього рівня, потреба в актуалізації й реалізації власного потенціалу, 
сприяють реалізації творчого підходу до роботи з колективом та інші переваги, яких набагато більше ніж недоліків.

Розгляд різних методологічних підходів до проблеми формування організаційно-методичної компетентості майбутніх фахівців сфрери обслуговування підвів нас до розуміння необхідності перенесення результатів дослідження в практичну площину, визначення умов їх практичного застосування. На цьому будується праксеологічний підхід до розв'язання науково-прикладних досліджень.

У педагогічній практиці праксеологічний підхід тлумачиться як результативність навчального процесу або ефективна діяльність. Для того щоб досягти бажаного результату навчання необхідно спланувати, організувати та здійснити доцільно організовану, продуктивну, логічно-послідовну діяльність з дотриманням норм та вимог. Сутність праксеологічного підходу до процесу фрормування організаційно-методичної компетентності майбутніх фрахівців сфери обслуговування полягає в організації навчально-методичної діяльності студента з позиції доцільності (відповідності наміченій меті), раціональності (осмисленості та обірунтованості), ефективності (приведення до потрібного результату).

Розглядаючи комплексну складова професійної компетентності таку як організаційно-методична компетентність варто розмежувати її окремі, але взаємопов'язані, компоненти: організаційний та методичний.

Організаційний компонент компетентності збагачує особистість такими якостями як відповідальність, дисциплінованість, пунктуальність, а також навичками самоорганізації й взаємодії 3 суб'єктами навчальної, а у майбутньому професійної діяльності. Методичний компонент об'єднує у собі зміст, фрорми та методи (технології) профессійної діяльності. Поєднання цих компонент в єдину комплексну компетентність вважаємо доцільним, оскільки саме доцільна ефективна організація забезпечує максимально продуктивну методично-сплановану професійну діяльність.

Формування організаційно-методичної компетентності майбутніх фахівців сфери обслуговування у першу чергу покладається на педагогів та майстрів виробничого навчання закладів професійної освіти.

Необхідними умовами є бажання і готовність педагогів технікумів і коледжів до інноваційної діяльності, модернізації змісту, їх готовності до особистісно-професійного саморозвитку; підтримувати сприятливий психологічний клімат у колективі, усвідомлювати важливістю й необхідність підготовки компетентного фахівця, а не просто особи, яка володіє деякими теоретичними знаннями та практичними вміннями.

Пріоритетність професійних компетентностей зумовлена й функціями, які вони виконують у життєдіяльності кожної людини, а саме: формування в особистості здатності навчатися і самонавчатися; забезпечення майбутнім фахівцям здатності до гнучкості та професійної мобільності; підвищення соціальної активності, конкурентоспроможності випускника в умовах ринку праці.

Таким чином, виокремлення з переліку професійних компетентностей організаційно-методичної та розроблення навчально-методичного комплексу щодо формування означеної компетентності майбутніх фрахівців сфери ресторанного обслуговування сприятиме усуненню їх дублювання у процесі набуття інших професійно-значимих компетнтностей і забезпечить їхнє взаємодоповнення та інтеграцію задля якісної підготовки висококваліфікованих робітників сфери обслуговування.

\section{V Висновки}

В основі процесу формування професійних компетентностей студентів лежить спільне завдання розвиток здатності до самоосвіти, професійної мобільності та активності, спрямування діяльності майбутніх фахівців на досягнення якісного результату, розвиток здатності до самореалізації.

Отже, професійна підготовка за змістом і формами ії організації та проведення має бути процесом, у якому формуванню профресійним компетентностям необхідно приділяти таку саму увагу, як і оволодінню фаховими знаннями, уміннями та навичками. 
При цьому питома вага у формуванні професійних компетентностей у фраховій підготовці здебільшого належить організаційно-методичній компетентності, сутність якої полягає у наступному:

- підготовленості майбутніх фахівців сфери обслуговування до самостійного виконання просресійних виробничих завдань,

- у уміння оцінювати виконання праці,

- здатності самостійно здобувати нові знання й уміння;

- здатності до колективної діяльності і співробітництва з іншими працівниками,

- готовності до прийняття на себе відповідальності за результати своєї праці;

- готовності до постійного підвищення професійної майстерності та особистісних якостей,

- здатності до самомотивування, рефлексії, саморозвитку особистості в професійній діяльності.

\section{Бібліографрічні посилання}

[1] Адаптивне управління розвитком професійної освіти : колективна монографія. Г. В. Єльникова та ін. ; за заг. та наук. ред. Г. В. Єльникової. Павлоград: ІМА-прес, 2016. 248 с.

[2] Радкевич В. О. Компетентнісний підхід до розроблення Державних стандартів профресійно-технічної освіти Профресійно-технічна освіта. 2012. № 3. С. 8-10.

[3] Національна стратегія розвитку освіти в Україні на період до 2021 року URL: http://zakon4.rada.gov.ua/laws/show/344/2013 (дата звернення 28.03.2019).

[4] Пометун О. І. Дискусія українських педагогів навколо питань запровадження компетентнісного підходу в українській освіті Компетентнісний підхід у сучасній освіті. Світовий підхід та українські перспективи / за заг. ред. О. В. Овчарук. Київ, 2004. 112 с.

[5] Ягупов В. В. Ключові компетентності: поняття, сутність, зміст, класифікація та вимоги до випускників професійнотехнічної освіти Вісник Дніпропетровського університету імені Альфрреда Нобеля. Серія: Педагогіка і психологія. 2015. № 1(9). C. 193-199.

[6] Щокин Г. В. Закони соціального розвитку і управління. Київ : МАУП, 2006. 192 с.

[7] Довідник кваліфікаційних характеристик професій працівників / М-во праці та соц. політики України (Мінпраці та соцполітики) URL : http://uazakon.com/document/spart20/inx20247.htm (дата звернення 27.03.2019).

[8] Шапран О. І. Компетентнісний підхід до організації педагогічної практики студентів. Гуманітарний вісник. Спец. вип. Педагогіка : зб. наук. пр. Переяслав-Хмельницького державного педагогічного університету імені Григорія Сковороди. 2012. Вип. 26. С. 354-358.

[9] Гайовий І.І. Ефективність практичної підготовки фахівця ресторанної справи Сучасні інфоормаційні технології та інноваційні методики навчання у підготовці фахівців: методологія, теорія, досвід, проблеми : зб. наук. пр. КиївВінниця : ТОВ фірма «Планер», 2009. Вип. 22. С. 143-149.

[10] Зимняя И.А. Ключевые компетенции - новая парадигма результата образования Дайджест педагогічних ідей $i$ технологій. № 4. 2003. С.18-23.

\section{References}

[1] Yelnikova H.V. (ed.) (2016). Adaptyvne upravlinnia rozvytkom profesijnoyi osvity: Kolektyvna monografiya [Adaptational management of the development of vocational education]. Pavlohrad, IMA-press.

[2] Radkevych V.O. (2012). Kompetentnisny pidkhid do rozroblennia Derzhavnykh standartiv profesijno-tekhnichnoyi osvity [Competence-based approach to the development of the State standards of vocational education]. Profesijno-tekhnichna osvita [Vocational education], 3, 8-10.

[3] Natsionalna strategiya rozvytky osvity v Ukrayini na period do 2021 roku [National strategy for the development of education in Ukraine for the period until 2021] (2013). [Online]. Available from: https://zakon4.rada.gov.ua/laws/show/344/2013 [Accessed on April 3rd, 2019].

[4] Pometun O. I. (2004) Dyskusiia ukrainskykh pedahohiv navkolo pytan zaprovadzhennia kompetentnisnoho pidkhodu v ukrainskii osviti [Discussion of Ukrainian Teachers on Issues of Implementing a Competency Approach in Ukrainian Education]. Kompetentnisnyi pidkhid u suchasnii osviti. Svitovyi pidkhid ta ukrainski perspektyvy [Competency approach in modern education. Global approach and Ukrainian perspectives]. Kiev, "K.I.S.".

[5] Yahypov V.V. (2015) Kliuchovi kompetentnosti: poniattia, sutnist, zmist, klasyfikatsiya ta vymohy do vypusknykiv profesijnotekhnichnoyi osvity [Key competences: notion, essence, content, classification and requirements for the graduates of vocational institutions]. Visnyk Dnipropetrovskoho universytetu imeni Alfreda Nobelia. Seriya: Pedahohika i psykholohiya. Pedahohichni nauky [Dnipropetrovsk Alfred Nobel University Journal. Series: Pedagogy and psychology. Pedagogical sciences], 1(9), 193-199.

[6] Schokyn H.V. (2006). Zakony sotsialnoho rozvytku i upravlinnia [Laws of social development and management]. Kyiv, Interregional Academy of Personnel Management. 
[7] Ministry of Labor and Social Policy of Ukraine (2001). Dovidnyk kvalifikatsijnykh kharakterystyk profesij pratsivnykiv [Directory of qualification characteristics of workers' professions]. [Online] Available from: http://uazakon.com/document/ spart20/inx20247.htm [Accessed on April 3rd, 2019].

[8] Shapran O.I. (2012). Kompetentnisny pidkhid do orhanizatsiyi pedahohichnoyi praktyky studentiv [Competence-based approach to the organization of students' pedagogical practice]. Humanitarny visnyk. Spetsialny vypusk. Pedahohika [Humanities journal. Special issue. Pedagogy], 26, 354-358.

[9] Hayovy I.I. (2009). Efektyvnist praktychnoyi pidhotovky fakhivtsia restorannoyi spravy [Effectiveness of practical training of a restaurant service specialist]. Suchasni informatsijni tekhnologiyi na innovatsijni metodyky navchannia u pidhotovtsi faknivtsiv: metodolohiya, teoriya, dosvid, problemy [Modern information technologies and innovative methods of educating and training specialists: methodology, theory, experience, problems], 22, 143-149.

[10] Zimniaya I.A. (2003). Kliuchevyie kompetentsii - novaya paradigma rezultata obrazovaniya [Key competences - new paradigm of the outcome of education]. Daidzhest pedahohichnykh idei i tekhnolohii [Digest of pedagogical ideas and technologies], 4, 18-23.

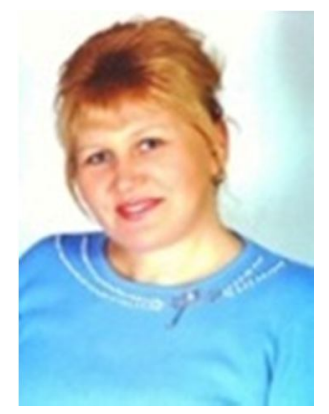

\section{Огуй Світлана Володимирівна.}

викладач вищої категорії, методист Полтавського кооперативного коледжу, аспірант кафедри основ виробництва та дизайну,

Полтавський національний педагогічний університет імені В. Г. Короленка,

вул. Остроградського, 2, м. Полтава, Україна 36000.

E-mail: svetlana.oguj@gmail.com

\section{Ohui Svitlana Volodymyrivna.}

Teacher of higher category, methodologist of the Poltava cooperative college,

Post-graduate student of the Department of Production and Design Principles,

Poltava V.G. Korolenko National Pedagogical University, vul. Ostrohradskoho, 2, Poltava, Ukraine, 36000.

E-mail: svetlana.oguj@gmail.com

\section{Citation (APA):}

Ohui, S. (2019). Methodological basis of forming organizational competence of future specialists in service industry. Engineering and Educational Technologies, 7 (2), 71-79. doi: https://doi.org/10.30929/2307-9770.2019.07.02.07

\section{Цитування (ДСТУ 8302:2015):}

Огуй С. В. Методологічні основи формування організаційно-методичної компетентності майбутніх фрахівців сфери обслуговування / Інженерні та освітні технології. 2019. Т. 7. № 2. С. 71-79. doi: https://doi.org/10.30929/23079770.2019.07.02.07

Обсяг статmі: $\quad$ сторінок - 9 ; умовних друк. аркушів - 1,304. 